Travaux du Muséum National d'Histoire Naturelle «Grigore Antipa»
Vol. 61 (1)

pp. $7-11$

\title{
On the Presence of the European Medicinal Leech Hirudo medicinalis Linnaeus, 1758 (Annelida: Hirudinea) in Romania
}

\author{
Victor SURUGIU*
}

\begin{abstract}
"Alexandru Ioan Cuza" University of Iași, Faculty of Biology, 20A Carol I Blvd., RO-700507, Iaşi, Romania

*corresponding author, e-mail: vsurugiu@uaic.ro
\end{abstract}

Received: August 5, 2017; Accepted: March 13, 2018; Available online: May 9, 2018; Printed: June 30, 2018

\begin{abstract}
An isolated, but persistent population of the European medicinal leech Hirudo medicinalis Linnaeus, 1758 is reported from the "Mestecănișul de la Reci" Natural Reserve (ROSCI0111, Covasna County), representing the first confirmed record of this species in Romania. Information regarding habitat characteristics, main diagnostic features and protection status of the species is presented.
\end{abstract}

Key words: Hirudo medicinalis, Hirudo verbana, Romania, distribution, conservation management.

Six species of medicinal leeches (Hirudo spp.) are currently recognized worldwide, all of them with Palearctic distribution: the European medicinal leech Hirudo medicinalis Linnaeus, 1758, the North-African "dragon" or "trout leech" Hirudo troctina Johnson, 1816, the Mediterranean medicinal leech Hirudo verbana Carena, 1820, the Korean blood-sucking leech Hirudo nipponia Whitman, 1886, the Persian or Georgian medicinal leech Hirudo orientalis Utevsky \& Trontelj, 2005, and the recently described Hirudo sulukii Saglam, Saunders, Lang \& Shain, 2016 (Utevsky \& Trontelj, 2005; Utevsky et al., 2010; Saglam et al., 2016). Although the medicinal leeches are characterized by great intraspecific colouration variability, the species can be readily distinguished by the colouration pattern (Hechtel \& Sawyer, 2002; Utevsky \& Trontelj, 2005; Saglam et al., 2016). In spite of being one of the beststudied invertebrate species, information on quantitative ecology of medicinal leeches in the wild is still very limited (Elliott \& Kutschera, 2011; Kutschera \& Elliott, 2014).

In Romania, all previous reports of medicinal leeches referred to as $H$. medicinalis (Scriban, 1904, 1910, 1915; Epure, 1944; Cristea \& Manoleli, 1977). Scriban $(1904,1910)$ even mentioned the occurrence in Romania of five colour varieties of H. medicinalis (serpentina, tesselata, signata, communis and nigrescens). In spite of this, recent studies (Gagiu, 2010; Fermaș \& Cristofor, 2013; Surugiu, 2015) revealed that in Romania all populations belong to $H$. verbana only.

However, on the $3^{\text {rd }}$ of July 2016, two individuals with a pigmentation pattern, typical of $H$. medicinalis, were collected from a small eutrophic swamp in the "Mestecănișul de la Reci" Natural Reserve $\left(45.82287^{\circ} \mathrm{N}, 25.9266^{\circ} \mathrm{E}\right.$; ROSCI0111; Covasna County). The repeated sampling, on the $10^{\text {th }}$ of July 2016, provided additional five adult and two juvenile specimens. All collected specimens are deposited in the collection of the "Grigore Antipa" National Museum of Natural History, Bucharest, Romania (MGAB ANN 002) and in the author's personal collection.

The habitat where $H$. medicinalis were collected is situated at an altitude of $534 \mathrm{~m}$ a.s.l. The estimated surface area of the swamp is of $604 \mathrm{~m}^{2}$, the depth is 
less than $0.5 \mathrm{~m}$, and the substrate is muddy. Emergent vegetation is represented by broadleaf cattail (Typha latifolia) and rush (Juncus sp.), whilst the submerged plants were represented by European white water lily (Nymphaea alba), frogbit (Hydrocharis morsus-ranae), and common duckweed (Lemna minor) (Fig. 1). On the second sampling occasion, the following environmental parameters were recorded in the field: $21.6^{\circ} \mathrm{C}$ for water temperature, 7.10 for $\mathrm{pH}, 0.75 \mathrm{mg} . \mathrm{l}^{-1}$ for dissolved oxygen concentration (8.5\% saturation), $68.9 \mu \mathrm{S} . \mathrm{cm}^{-1}$ for conductivity, and $39.2 \mathrm{mg} . \mathrm{l}^{-1}$ for TDS (measured with a portable CONSORT C535 Water Quality Meter).

Adults of $H$. medicinalis measured $74.0-78.5 \mathrm{~mm}$ long, $11.0-11.5 \mathrm{~mm}$ wide and with the posterior sucker diameter (PSD) of $6.5-7.5 \mathrm{~mm}$; young leeches were $39.0 \mathrm{~mm}$ long, 5.0-6.0 $\mathrm{mm}$ wide, and 3.5-4.0 $\mathrm{mm}$ PSD. The individuals are characterized by two sharply delimited pairs of longitudinal red stripes interrupted by metamerically arranged black, drop-like markings on generally olive-green to brown dorsal background and by irregularly distributed black spots on yellow to light greenish ventral side (Fig. 2).

Thus, in Romania, there are present two species of medicinal leeches: the common $H$. verbana and a much rarer $H$. medicinalis. As suggested by Utevsky et al. (2010), in Romania, H. medicinalis seems to be restricted to the deciduous arboreal zone (in this case a birch forest), while $H$. verbana prefers steppe landscapes.

Distribution: confirmed records for the occurrence of $H$. medicinalis are from United Kingdom, Denmark, southern Norway, Sweden, Finland, France, Belgium, the Netherlands, Luxembourg, Germany, Poland, Lithuania, Latvia, Estonia, Belarus, Russian Federation eastward to the southern Ural Mountains and probably as far

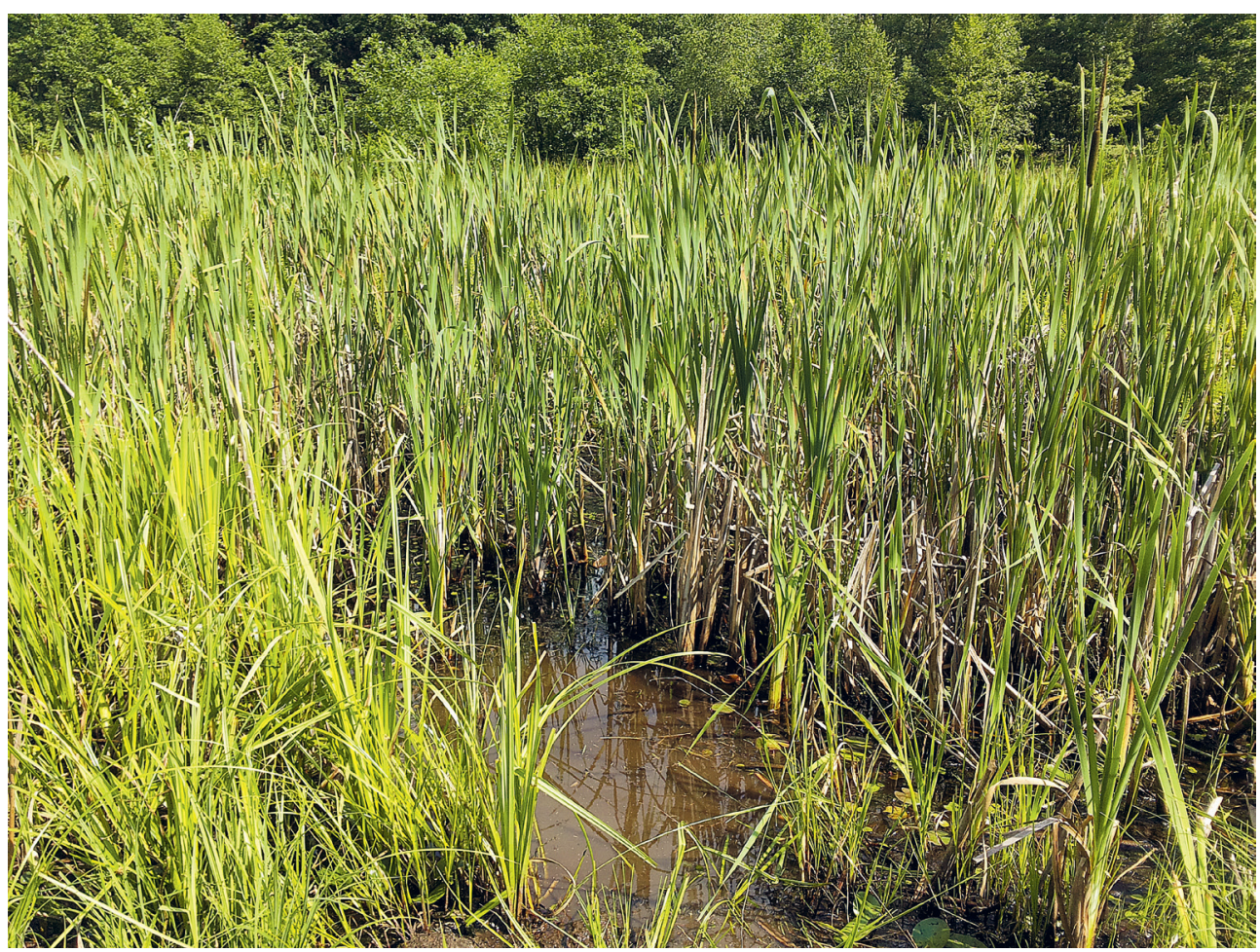

Fig. 1 - Habitat of Hirudo medicinalis at the "Mestecănișul de la Reci” Natural Reserve. 


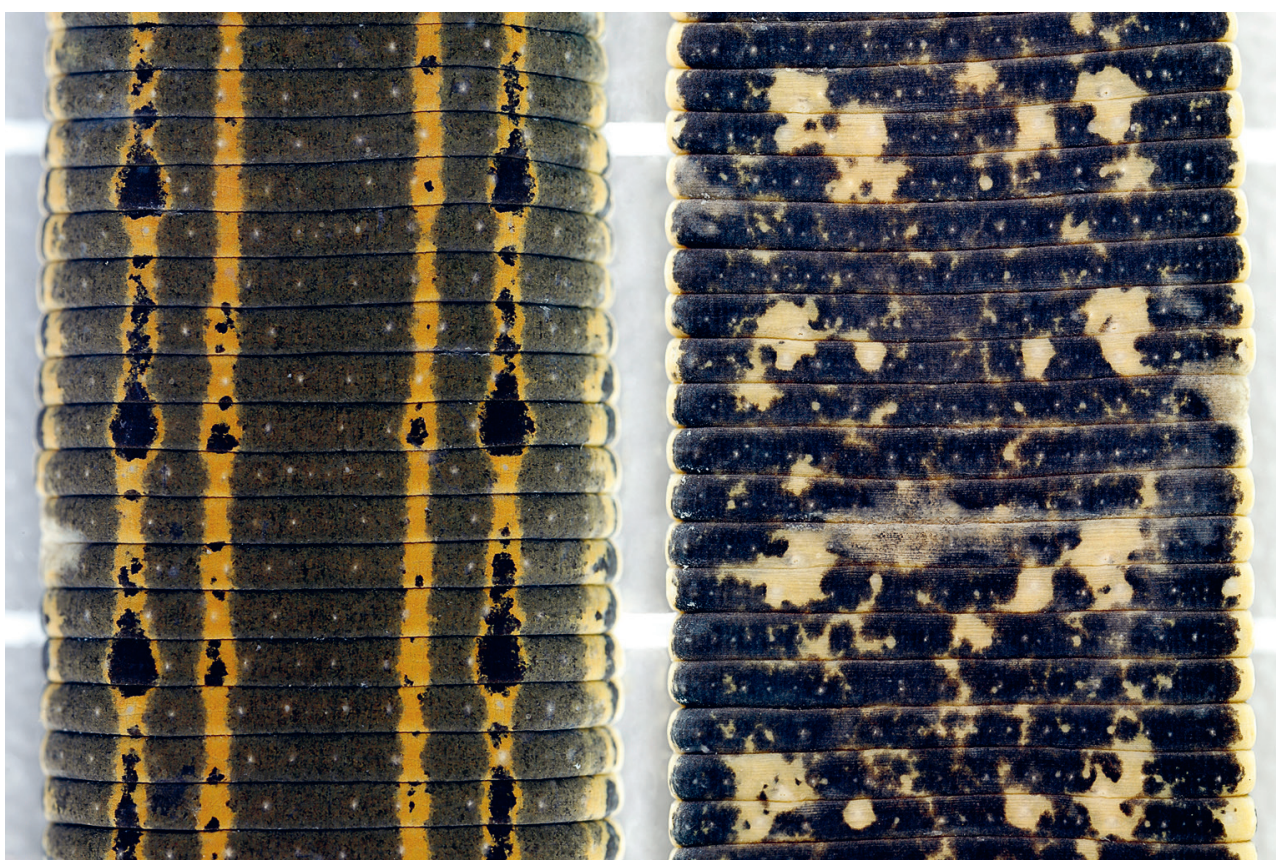

Fig. 2 - Dorsal (in the left) and ventral (in the right) pigmentation pattern of Hirudo medicinalis from "Mestecănişul de la Reci" natural reserve (scale lines $10 \mathrm{~mm}$ apart).

as the Altai Mountains, Switzerland, Austria, Hungary, Czech Republic, Slovakia, Ukraine, Slovenia, Croatia (Utevsky et al., 2010; Elliott \& Kutschera, 2011) and Romania (new record).

Wild populations of the European medicinal leech are threatened in most of the European countries as result of wetland habitats alteration and loss, global decline of amphibian populations, abandonment of traditional grazing practices (troughs are now used instead of ponds for the watering of farm animals) and extensive over-collecting for medical purposes (Utevsky et al., 2010; Elliott \& Kutschera, 2011; Kutschera \& Elliott, 2014). H. medicinalis is currently classified as NT category ("near threatened") in the IUCN Red List (Utevsky et al., 2014), included in Appendix III of the Bern Convention (Council of Europe, 1979), in Appendix II of the CITES (1979; ratified by National Law No. 69/1994) and in Annex Va of the Habitats Directive (Council Directive 92/43/EEC). H. medicinalis from "Mestecănișul de la Reci" Natural Reserve is believed to represent a boreal-continental relict population. Though this small population seems to be viable due to the presence of juvenile medicinal leeches, rich amphibian host populations (Pelophylax lessonae, Rana arvalis, Triturus cristatus) and obvious evidence that the habitat is frequented by cattle for the watering (banks of water presented numerous footprints), it is critically endangered because marshes and ponds within the protected area are menaced by gradual drying out. Thus, further regular monitoring of this population is necessary to envisage effective conservation actions for this rare species in Romania. 


\section{ACKNOWLEDGEMENTS}

Ștefan Zamfirescu ("Alexandru Ioan Cuza" University of Iași, Romania) is kindly acknowledged for indicating on the occurrence of medicinal leeches in the "Mestecănișul de la Reci" Natural Reserve and for providing data on amphibian species. I am also indebted to Ciprian Mânzu ("Alexandru Ioan Cuza" University of Iași, Romania) for the help in identification of aquatic plants. All my gratitude is expressed to Serge Utevsky ("V.N. Karazin" Kharkiv National University, Ukraine) for the valuable discussions on the subject. I would like also to thank two anonymous reviewers for critical reading of the manuscript.

\section{REFERENCES}

CRISTEA, V., D. MANOLELI (1977) Conspectus des Sangsues (Hirudinea) de Roumanie, avec une clé de détermination. Travaux du Muséum National d'Histoire Naturelle "Grigore Antipa", 18: 23-56. (in French)

ELLIOTT, J. M., U. KUTSCHERA (2011) Medicinal leeches: historical use, ecology, genetics and conservation. Freshwater Reviews, 4: 21-41.

EPURE, E. X. (1943) Die Fauna der Hirudineen im Banat. Annales Scientifiques de l'Université de Jassy, 29 (2): 557-563. (in German)

FERMAȘ, T. A., S. CRISTOFOR (2013) Contributions to knowledge of structural dynamics of the populations of medicinal leeches in the Braila marshes complex / the lower Danube wetland system. Analele Științifice ale Universității "Alexandru Ioan Cuza" Iași, Seria Biologie animală (suppl.): 29-36.

GAGIU, A. (2010) The first recorded occurrence of Hirudo verbana Carena, 1820 (Hirudinea: Arhynchobdellida: Hirudinidae) in Romania. Travaux du Muséum National d'Histoire Naturelle "Grigore Antipa", 53: 7-11.

HECHTEL, F. O. P., R. T. SAWYER (2002) Toward a taxonomic revision of the medicinal leech Hirudo medicinalis Linnaeus, 1758 (Hirudinea: Hirudinidae): re-description of Hirudo troctina Johnston, 1816 from North Africa. Journal of Natural History, 36: 1269-1289.

KUTSCHERA, U., J. M. ELLIOTT (2014) The European medicinal leech Hirudo medicinalis L.: Morphology and occurrence of an endangered species. Zoosystematics and Evolution, 90 (2): 271-280.

SAGLAM, N., R. SAUNDERS, S. A. LANG, D. H. SHAIN (2016) A new species of Hirudo (Annelida: Hirudinidae): historical biogeography of Eurasian medicinal leeches. BMC Zoology, 1 (1): 1-12.

SCRIBAN, I. A. (1904) Contribution à la Faune des Hirudinées d'eau douce de Roumanie. Annales Scientifiques de l'Université de Jassy, 3 (1): 17-20. (in French)

SCRIBAN, I. A. (1910) Contributions à l'anatomie et à l'histologie des Hirudinées. Annales Scientifiques de l'Université de Jassy, 6 (4): 147-286. (in French)

SCRIBAN, I. A. (1915) Studii histologice și anatomice asupra hirudineelor de apă dulce și marine. Publicațiunile Fondului Vasile Adamachi, Academia Română, Socec, București, vol. 43, pp. 1-223. (in Romanian)

SURUGIU, V. (2015) Annelida. In: Iorgu, I. Ș. (Eds) Ghid sintetic pentru monitorizarea speciilor de nevertebrate de interes comunitar dỉ România, București, S.C. Compania de Consultanță și Asistență Tehnică S.R.L. și S.C. Integra Traiding S.R.L. București, 159 pp. (in Romanian)

UTEVSKY, S., P. TRONTELJ (2005) A new species of the medicinal leech (Oligochaeta, Hirudinida, Hirudo) from Transcaucasia and an identification key for the genus Hirudo. Parasitology Research, 98: 61-66.

UTEVSKY S., M. ZAGMAJSTER, A. ATEMASOV, O. ZINENKO, O. UTEVSKA, A. UTEVSKY, P. TRONTELJ (2010) Distribution and status of medicinal leeches (genus Hirudo) in the Western Palaearctic: anthropogenic, ecological, or historical effects? Aquatic Conservation: Marine and Freshwater Ecosystems, 20: 198-210.

UTEVSKY, S., M. ZAGMAJSTER, P. TRONTELJ (2014) Hirudo medicinalis. The IUCN Red List of Threatened Species, Version 3.1: e.T10190A21415816. Available at: http://dx.doi.org/10.2305/ IUCN.UK.2014-1.RLTS.T10190A21415816.en, accessed on 2017.08.05.

*** COUNCIL DIRECTIVE 92/43/EEC of 21 May 1992 on the conservation of natural habitats and of wild fauna and flora. Official Journal L 206, 22/07/1992 P. 0007-0050. Consolidated version 01.01.2007. Available at: http://ec.europa.eu/environment/nature/legislation/habitatsdirective /index en.htm, accessed on 2017.07.12.

*** COUNCIL OF EUROPE (1979) Convention on the Conservation of European Wildlife and Natural Heritage. Bern, Switzerland. European Treaty Series, No. 104, 19.IX.1979. Available at: http:// conventions.coe.int/Treaty/EN/Treaties/html/104.html, accessed on 2017.07.27. 
*** CITES (1973) Convention on the International Trade in Endangered Species of the Wild Fauna and Flora. Appendices I, II and III valid from 4 April 2017. Available at: https://www.cites. org/eng/app/appendices.php, accessed on 2017.07.27. 